\title{
THE GENUS DRYOPTERIS (PTERIDOPHYTA: DRYOPTERIDACEAE) IN THE FLORA OF THE REPUBLIC OF MACEDONIA - 30 YEARS AFTER MICEVSKI'S FLORA -
}

\author{
Ljupčo Melovski \\ Institute of Biology, Faculty of Natural Sciences and Mathematics, Ss. Cyril and Methodius University, \\ Skopje, Republic of Macedonia \\ melovski@pmf.ukim.mk
}

This article presents the records about four new Buckler fern (Dryopteris) species for the territory of the Republic of Macedonia and new data about the distribution of some rare Buckler fern species.

Dryopteris is one of the most complex fern genera in Europe. Hybridization and apomixis among some of the species contribute to difficulties and uncertainties for identification of individual species. That, coupled with lack of research on ferns in Macedonia for the last 30 years, resulted in a low level of knowledge within this vascular plants' group.

The field research of the flora of Macedonia and thorough check of two herbaria (MKMEL and MKNH) in Skopje revealed presence of four new Buckler fern species in Macedonia: Dryopteris affinis subsp. jessenii, D. oreades, D. mindshelkensis and D. expansa. Additionlly, several other localities for rare species: $D$. borreri, $D$. dilatata and D. carthusiana were reported.

Further research is needed to fill the remaining gaps, particularly in relation to identification of hybrids and more detailed study of the distribution pattern of rare Buckler fern species.

Key words: Dryopteris affinis; Dryopteris oreades; Dryopteris mindshelkensis; Dryopteris expansa; Republic of Macedonia; rare ferns

\section{INTRODUCTION}

Buckler fern (Dryopteris Adans.) stands for one of the most complex genera among the European pteridophytes. According to Plant List [1], genus Dryopteris includes 1,458 accepted and unassessed names of species rank and 35 names of infraspecific rank worldwide (http://www.theplantlist.org/). At the same time, Euro+Med Plant Base [2] recognizes 30 Dryopteris species and 11 subspecies in Europe and Mediterranean region [2]. Beside the relatively high number of species in the genus, the complexity comes from the high level of hybridization among many different species and subsequent apomictic reproduction characteristics for some of the species (Dryopteris affinis group in particular), Fraser-Jenkins [3, 4]. Hybridization and apomixis are the main reasons for the origin of some species, morphologically separated by fine discrete characters [4]. Owing to above reasons, there was considerable confusion about Dryopteris taxonomy, thus resulting with complex synonymy and different treatment in existing standard floras, which makes identification of the particular species difficult and in some cases problematic. This particularly stands for the taxa of D. affinis group for which the concept of Fraser-Jenkins [4] is now accepted by the majority of researcher (see Euro+Med PlantBase) [2].

In the flora of the Republic of Macedonia six Dryopteris species are known so far, Micevski [5]: Dryopteris filix-mas (L.) Schott, D. borreri (Newman) Newman ex Oberh. \& Tavel, D. villarii (Bellardi) Schinz \& Thell., D. pallida (Bory) Maire \& Petitm., D. carthusiana (Vill.) H. P. Fuchs, and D. 
dilatata (Hoffm.) A. Gray. Extensive and detailed research in that time and after printing of Micevski's Flora in 1985, [3, 4, 6-18] put a new light on the knowledge about the taxonomy and chorology of this genus. These data and some recent findings in Macedonia suggest that the representation of the Dryopteris species in the country might be underestimated.

The aim of this work was to explore the Dryopteris collections in MKMEL! and MKNH! [19], to identify the species in the light of the new concept for Dryopteris taxonomy and to distinguish potential new taxa. The final goal was to assess the status of the genus Dryopteris in the flora of the Republic of Macedonia.

\section{METHODS}

The study was based on the fieldwork on the territory of the Republic of Macedonia during the last two decades and the collected and stored plant material in the Herbarium Melovskiorum (MKMEL!), as well as on the check of the Macedonian National Herbarium (MKNH!). The abbreviations of the herbaria follow Index Herbariorum [19]. Besides the field surveys, relevant literature sources were used for supplementation of the distribution records.

Identification of the specimens was performed on the basis of the keys from $[10 ; 15]$, as well as Fraser-Jenkins [4] for D. affinis group. The detailed morphological analyses and descriptions of individual species in [20-27] were valuable for proper identification. Beside the analysis of standard morphological characters, light microscopy was applied for identification of members of the $D$. $d i$ latata group. The spores were analyzed for perispore ornamentation rather than for dimensions of the spores. At least 10 spores from at least three herbarium specimens $(D$. dilatata and $D$. carthusi$a n a)$ or two specimens in case of $D$. expansa were analyzed. An effort was done to avoid spore contamination during preparation of glycerol slides (by taking spores only directly from the sporangia). Only few spores were photographed and presented in Figure 3 for comparison.

We followed the nomenclature of the taxa used in Euro+Med PlantBase [2]. The distribution of the species was mapped on $10 \times 10 \mathrm{~km}$ using the UTM grid system (UTM Zone 34T) and Military Grid Reference System (MGRS) projection [28], modified by Avukatov (unpublished) to $5 \mathrm{~km} \times 5$ $\mathrm{km}$ for the purpose of this paper. The quotation of the distribution locations and habitats for all records in this article follows the MAKMEL data base pattern. The regional division of Melovski et al. [29] was used to present the general geographic position of the localities.

\section{RESULTS AND DISCUSSION}

Among the known Buckler fern taxa in the Republic of Macedonia, D. filix-mas is the most frequent and abundant and D. villarii and D. pallida are frequently found on limestone mountains in western Macedonia, while $D$. borreri, D. carthusiana and D.dilatata are very rare species [5].

The present work adds four new Buckler fern species to the flora of the Republic of Macedonia and new distribution data for rare species.

Dryopteris affinis (Lowe) Fraser-Jenk. subsp. jessenii (Fraser-Jenk.) Fraser-Jenk., Fern Gaz. 18 (1): 5 (2007)

D. affinis is a diploid apomict which is nominal species of the complex Dryopteris affinis aggregate together with other seven species $[4,17]$. Up to now, five subspecies, including the nominal one, were described [4], out of which three can be found across the Balkan Peninsula: subsp. affinis in Slovenia, Croatia, Greece, Bulgaria (doubtful) and Romania; subsp. punctata in Slovenia and Croatia and subsp. jessenii in Serbia and Romania [2, but on the basis of $13 ; 4]$. The results of this article show that $D$. affinis subsp. jessenii is distributed in the Republic of Macedonia as well, where it was recorded only on Plačkovica Mt. (Figure 1). It was also recently reported for Poland [30].

\section{First chorological records}

Plačkovica: Selska Reka valley - above v. Laki (between Strumički Rid and Kartal - below and above the inflow of Lomska Reka), open grassy site next to the river in beech forest 930-950 m a.s.l., 24.10.2014, leg.\&det. Lj. Melovski (MKMEL! 08238); Plačkovica: Selska Reka valley - above v. Laki (next to the stream Lom), next to the stream in beech forest, $1110 \mathrm{~m}$ a.s.l., 11.09.2016, leg.\&det. Lj. Melovski (MKMEL! 08992, 08996-08998); Ibid., 1065 m a.s.l., (MKMEL! 09000-09002); Plačkovica: Selska Reka valley - above v. Laki (close to the stream of Selska Reka), at the edge of beech forest, $860 \mathrm{~m}$ a.s.1., 11.09.2016, leg.\&det. Lj. Melovski (MKMEL! 08999).

The finding of $D$. affinis subsp. jessenii far from its main range is curious. However the specimens found on Plačkovica Mt. have typical morphological characteristics of $D$. affinis subsp. jessenii (Fig. 2) as described by Fraser-Jenkins [4]. Besides, it is not a rare case that Carpathian species spread to the south in the north-eastern Macedonian mountains (e.g. Viola dacica Borb., [32]). The new finding in the southern (Carpathian) part of Poland [30] shows that the subspecies is spreading its range to the north as well. 


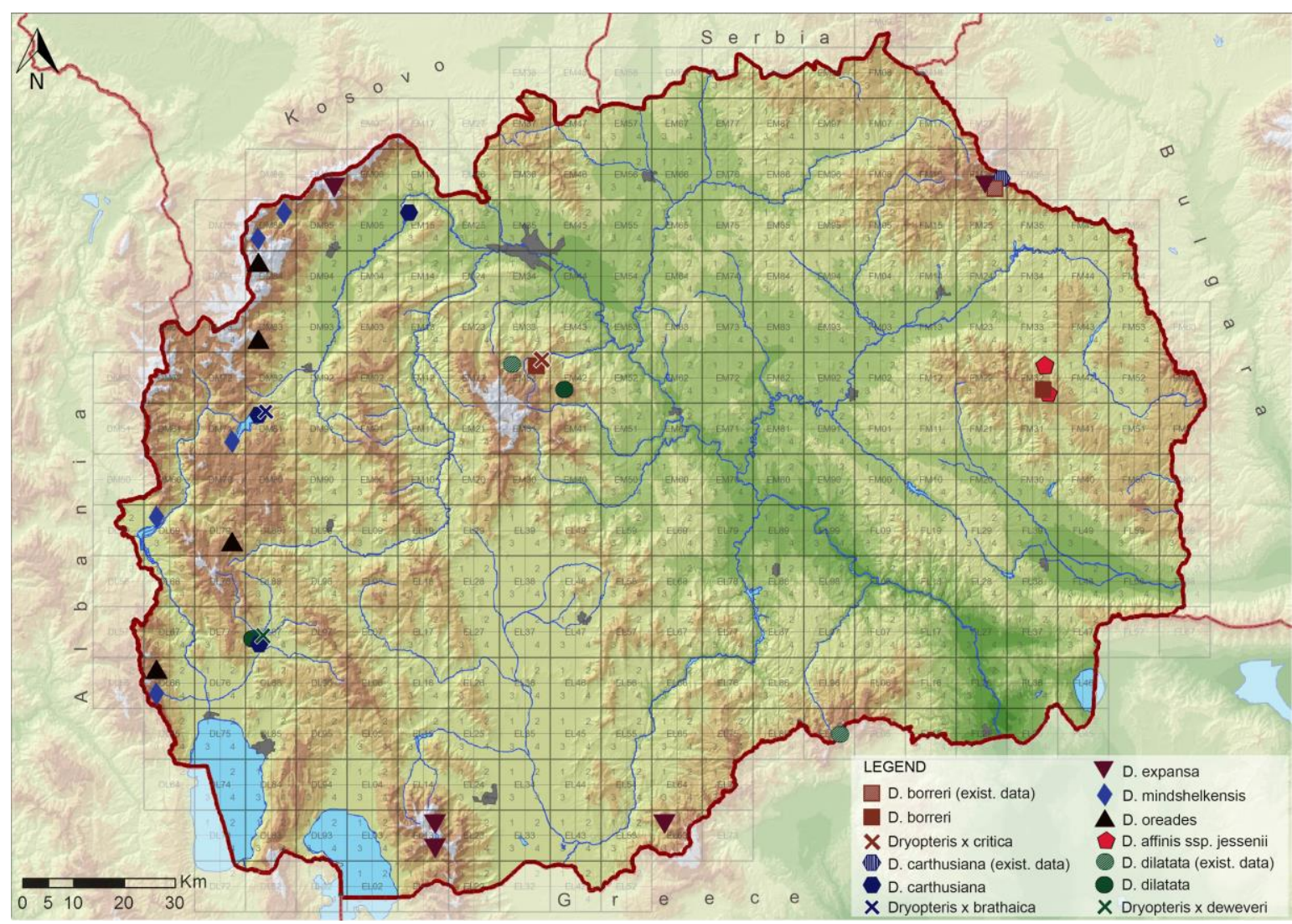

Figure 1. Distribution map of the first records, new records and literature data of the presented Dryopteris taxa in the Republic of Macedonia

Dryopteris borreri (Newman) Newman ex Oberh. \& Tavel, Verh. Schweiz. Naturf. Ges. 118: 153 (1937)

This triploid apomict is the most widespread species in the D. affinis group [4]. However, it is a rare species in Macedonia - the only known locality up to now was Osogovo Mts. [5] (Fig. 1). It can be relatively easily distinguished from $D$. affinis by its indusia which look more like those of $D$. filixmas, however in concordance with other morphological characters (Fig. 2).

\section{Existing chorological record}

Osogovo-Sasa. Beside the rocks close to the river. 1050 m.n.v. 15.VII.1967, leg. K. Micevski, det. Mayer \& Micevski (MKNH! 000301, 000302, 000312).

\section{New chorological records}

Plačkovica: Selska Reka valley - above v. Laki (next to the stream Lom), next to the stream in beech forest, $1035 \mathrm{~m}$ a.s.1., 11.09.2016, leg.\&det. Lj. Melovski (MKMEL! 09003, 09005, 09006); Mokra Planina - Golešnica: Mala Reka valley just below the junction of the Mumdžica and Sipačan streams, close to the stream in beech forest,
$950 \mathrm{~m}$ a.s.1., 25.09.2016, leg.\&det. Lj. Melovski (MKMEL! 09026).

The species remains rare (Figure 1) which is probably realistic since Macedonia is at the southern border of its range in Europe (excluding Turkey) [2]. It is also comparatively rare in Bulgaria and was only recently reported [24] if one considers that it is a common species in Europe.

Dryopteris oreades Fomin, Monit. Jard. Bot. Tiflis 18: 20 (1910)

Mountain male fern $(D$. oreades) has interesting, rather disjunct distribution range. It can be found in west and west-central Europe, extending to N.C. Italy [10], in the Caucasus region and Turkey as well as in Romania [2]. It is possible that it has been overlooked in the past researches in the fern floras, although it is easily recognizable by its sori (high indusium which lifts slightly and remains embracing sporangia even after spores' ripening, see Figure 2). Future research can reveal new findings. Taxonomic remarks: the 'scattered minute glands' on the underside of the pinnae of Macedonian plants cannot be seen, except for the youngest fronds; some of the plants have more or less acute teeth at the tips of the pinnules instead of blunt. 

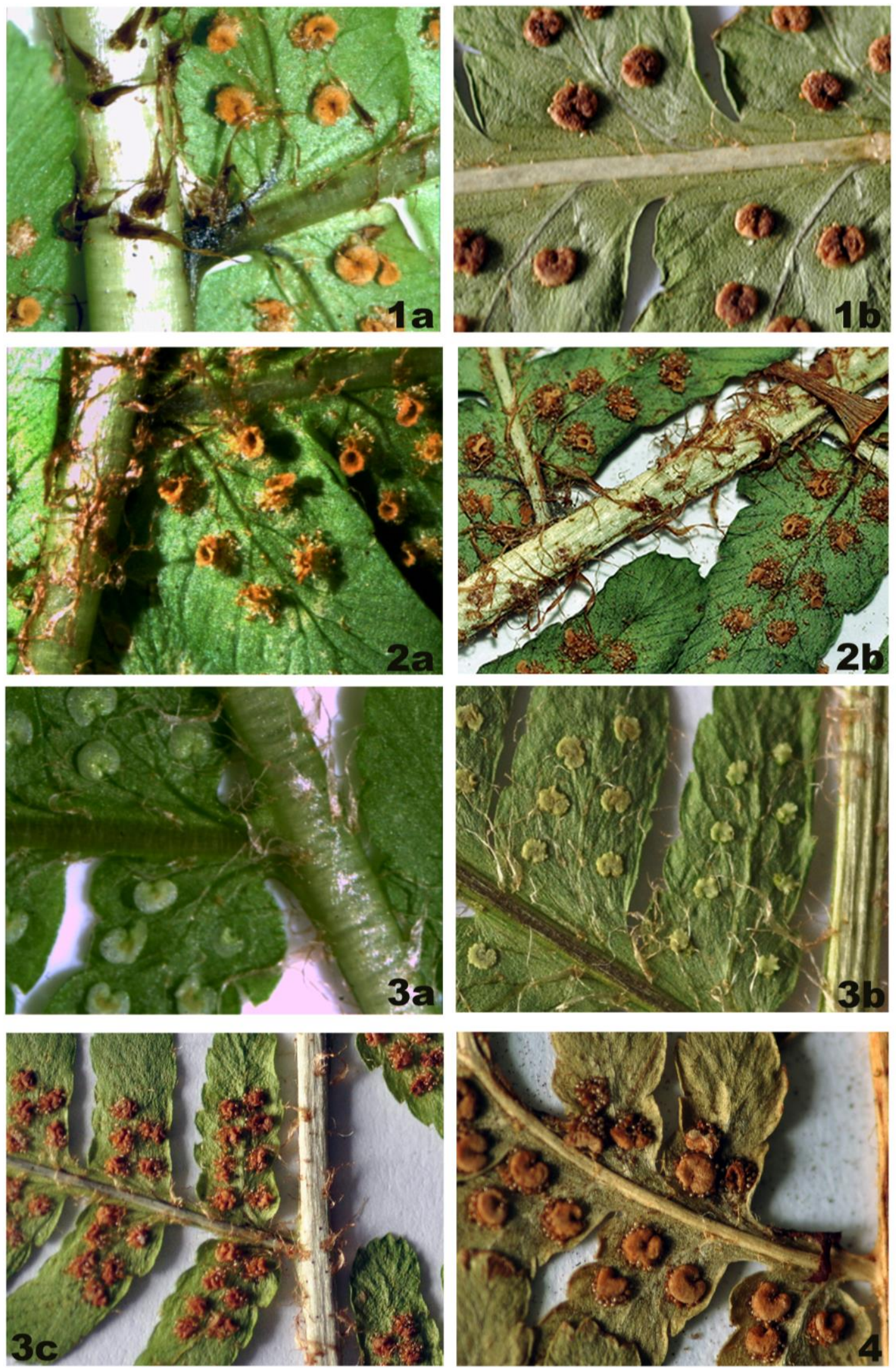

Figure 2. Sori with indusia and rachis scales of selected Dryopteris taxa

1) D. affinis subsp. jessenii (a - MKMEL! 08992; b - MKMEL! 08238).

2) D.borreri (a - MKMEL! 09006; b - MKMEL! 09005).

3) D. filix-mas - for comparison (a - young sori on live specimen; b - young sori on dessicated specimen, both from MKMEL! 09020; c - sori with ripe and mostly shed spores, from MKMEL! 09019).

4) D. oreades (MKMEL! 08215). 
In the Republic of Macedonia, this species is found on silicate rocky ground on the western mountains (Figure 1).

\section{First chorological records}

Šar Planina: Mengulova Kula - above v. Gorno Jelovce (above Ramen Kamen), silicate rocks, 2000 m a.s.l., 14.07.1998, leg. IDSB-Lj. Melovski, det. Lj. Melovski (MKMEL! 08195, 08196 and 08216); Šar Planina: Central massif - Titov Vrv (Golema Smreka), silicate stony site, $1900 \mathrm{~m}$ a.s.l., 08.09.2004, leg.\&det. Lj. Melovski (MKMEL! 08215); Jablanica: Crn Kamen massif - Krivi Virovi, silicate rocks, 1700-1800 m a.s.1., 08.06.2003, leg. Lj. Melovski, S. Arsovsa \& M. Šušlevska, det. Lj. Melovski (MKMEL! 08217); Stogovo: Valavica stream valley - below Jama, open place next to the road in beech forest, 1410 m a.s.l., 31.08.2016, leg.\&det. Lj. Melovski (MKMEL! 09024 and 0925).

Dryopteris mindshelkensis Pavlov, Vestn. Akad. Nauk Kazakhsk. SSR 8: 129. 1954

D. mindshelkensis is at present accepted name for widely known D. submontana (Fraser-Jenk. \& Jermy) Fraser-Jenk. It has similar distribution range as $D$. oreades, but it is characteristic only for mountains with calcareous bedrock. Beside Romania, on the Balkan it is present in Serbia, Montenegro, Albania and Greece [2]. Micevski [5] did not list this species in his Flora. However, two years after Micevski's flora has been published, Fraser-Jenkins (during his revision of Dryopteris material from MKNH!) identified three specimens as D. submontana wrongly identified as $D$. villarii by Micevski.

In the Republic of Macedonia, D. mindshelkensis is found on calcareous rocky ground on the western mountains (Figure 1).

\section{First chorological records}

Šar Planina: Kobilica - Golem Kamen, limestone rocks and stony ground, 1900-2050 m a.s.l., 01.10.2006., leg.\&det. Lj. Melovski (MKMEL! 08161); Šar Planina: Central massif - Krivošija (Treta Karpa - above Krivošiska Reka), limestone scree, 1740 m a.s.1., 20.07.1995, leg. IDSB-Lj. Melovski, det. Lj. Melovski (MKMEL! 08162); Jablanica: Čuma - Malo Sedlo, limestone rocks and stony ground, 1900-2000 m a.s.l., 10.08.2005, leg. Lj. Melovski \& N. Angelova, det. Lj. Melovski (MKMEL! 08163); Bistra: Toni Voda - close to the sinking stream, limestone stony ground - between large stones, $1700 \mathrm{~m}$ a.s.1., 22.08.2016., leg.\&det. Lj. Melovski (MKMEL! 08950 and 08951); Debarsko Krčin. Above the village of Gorno Kosovrasti, on limestone rocks. 1270 m.n.v., 19.VII.1960, leg. K.
Micevski, det. C. R. Fraser-Jenkins (MKNH! $000477-$ 000479).

\section{Dryopteris dilatata complex}

The complex consists of three species ( $D$. dilatata, D. expansa and D. carthusiana) which are known for difficult and uncertain identification [20, 3,25 , etc.] due to their high variability and interconnected origin. It is recommended that one should use a set of characters for identification rather than one or two usually used in standard keys. Many morphological characters were studied and involved (including dimensions and volume of the glands [33]), but still the perispore remains among the most important ones. In some keys [e.g. 10] $D$. dilatata perispore is described as being covered with dense and obtuse tubercles, and $D$. expansa perispore with sparse acute tubercles, which is not sufficient for identification of the two taxa, especially if the spores are examined by the light microscopy ("acute" and "obtuse" is not easily visible). Both $D$. dilatata and $D$. expansa have acute tubercles (or echinulae as R. L. L. Viane [33] names them) at least on light microscope images and the main difference is the density [33]; (see also Figure 3). D. expansa has well-spaced echinulae unlike $D$. dilatata with dense echinulae. Plants from Macedonia confirm this finding (Figure 3 ). Yet, traditionally accepted morphological characters used to distinguish the species in the group (particularly the length of the basioscopic pinnule) are sufficient to identify the majority of the specimens growing in Macedonia. However, in the frame of the considerable variation in fronds' morphology in this buckler fern group there are some individuals with characters that approach border values. In these cases the spores' morphology is important for proper identification.

Dryopteris dilatata (Hoffm.) A. Gray, Man. Bot. 631 (1848)

This species is distributed in the whole Europe excluding Montenegro and Albania where its presence is doubtful [2]. In Macedonia there was much confusion in regard to this species in the past. $D$. dilatata is listed in the Flora of Macedonia [5] for several localities: Pelister, Dudica, Jakupica Kadina Reka river, Osogovo. However, the revision of Buckler ferns in MKNH! by Fraser-Jenkins in 1987 (after the Flora has been published) showed that it was not present in Macedonia (all specimens from MKNH! were identified by Fraser-Jenkins as D. expansa). On the other hand, the research presented in this article showed that he misidentified the specimens from Dudica (Kožuf Mt.) and Mt. Jakupica (Kadina Reka river). 


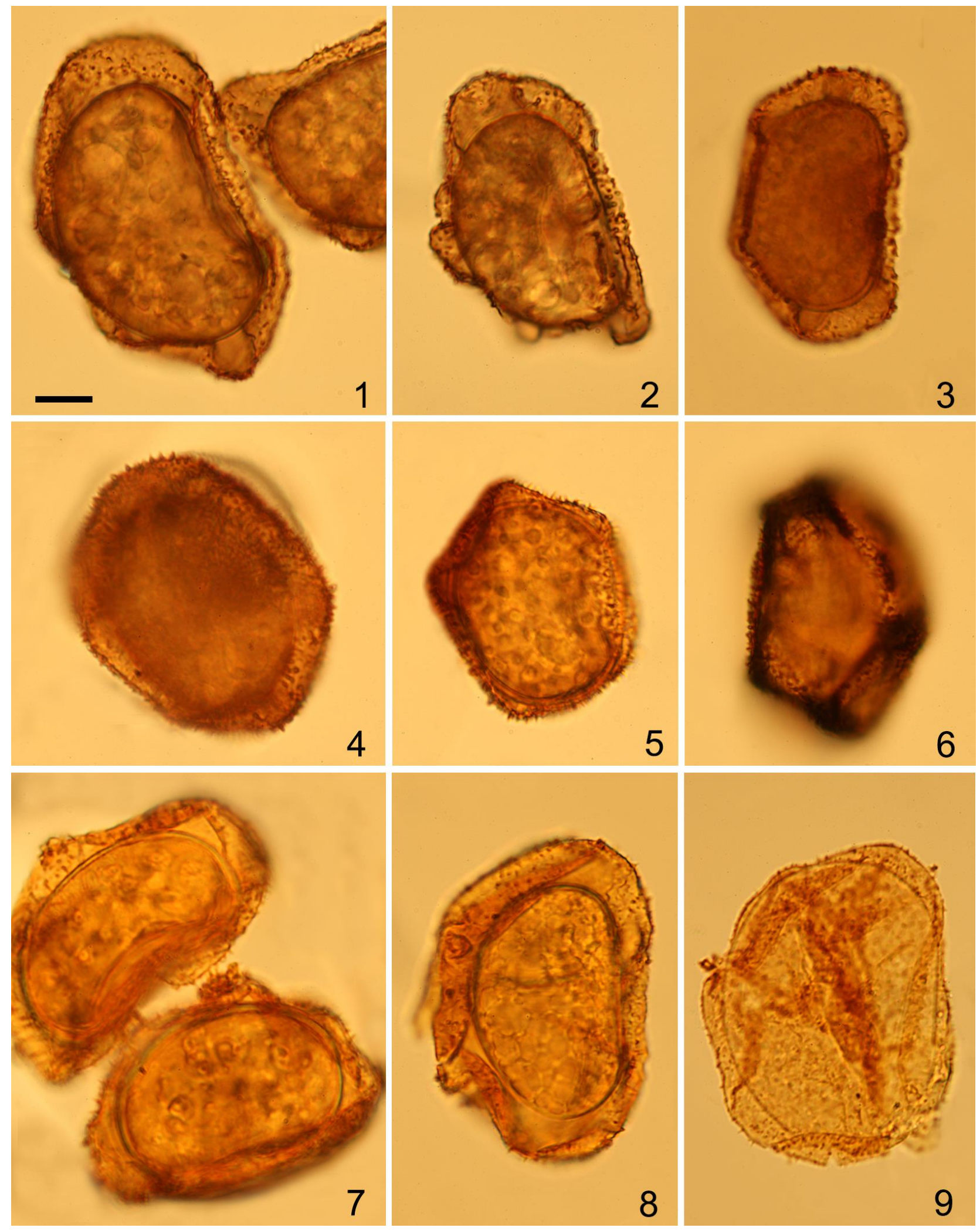

Figure 3. Spores of species of Dryopteris dilatata complex $(\times 1000)$ (scale bar $10 \mu \mathrm{m})$ 1-3 D. carthusiana: 1 - from Debarca - Belčiško Blato (MKMEL! 01940); 2 - from Debarca - Belčiško Blato (MKMEL! 08029); 3 - from Bistra-Šar Planina - Bunec (MKMEL! 00250)

4-6 D. dilatata: 4 - from Dudica (MKNH! 000318); 5 - from Dudica (MKNH! 000325); 6 - from Jakupica - Kadina Reka (MKNH! 000317)

7-9 D. expansa: 7 and 8 - from Osogovo (MKNH! 000310); 9 - from Pelister (MKMEL! 08076) 
These specimens certainly are $D$. dilatata, which was confirmed by microscopic analysis of the spores (Figure 3) and thorough analysis of the morphological characteristics, particularly the ratio between basioscopic and acroscopic pinnulae of the lowest pinna and the degree of the frond division. Spores are frequently pointed as quite certain character for separation of the two close species $-D$. dilatata and $D$. expansa, in some standard keys, including Flora Europaea [10]. Present distribution of D. dilatata in Macedonia is shown on Fig. 1.

Further research is needed to check the accuracy of the data given by old botanists from the beginning of 19-th century and mentioned in $\mathrm{Mi}-$ cevski [5].

\section{Existing chorological records}

Dudica - on humid ground, on andesite. 1500 m.n.v., 24.VIII.1978, leg.\&det. K. Micevski, confirmed by Lj. Melovski (MKNH! 000318-000325); Jakupica pl. - by the Kadina Reka river. 6.VIII.1953, leg.\&det. K. Micevski, confirmed by Lj. Melovski (MKNH! 000316 and 000317).

\section{New chorological records}

Debarca: Belčiško Blato - close to the v. Novo Selo, alder forest, $763 \mathrm{~m}$ a.s.1., 09.06.2009, leg.\&det. Lj. Melovski (MKMEL! 01941); Mokra Planina - Golešnica: Lisec - Pešterska Reka - from Klizište till the dale and higher, beech forest, 10001100 m a.s.l., 16.05.2007, leg.\&det. Lj. Melovski (MKMEL! 08072-08074).

Dryopteris expansa (C. Presl) Fraser-Jenk. \& Jermy, Fern Gaz. 11: 338 (1977)

According to Euro+Med PlantBase [2] D. expansa has very wide distribution in Europe. It is absent only from Macedonia, Albania, Montenegro, Croatia and Moldova. However, it seems that it is more frequent than $D$. dilatata in Macedonia (Figure 1; see also notes above, under 'Dryopteris dilatata' subchapter). As a matter of fact, most of the specimens in MKNH! actually belong to D. expansa, which was proved by microscopic analysis of the spores (Figure 3), thorough morphological analysis and revision of Dryopteris in MKNH! by Fraser-Jenkins in 1987.

\section{First chorological records}

Šar Planina: Čaušica-Peskovi-Bistra, in the crevices of silicate rocks, $2600 \mathrm{~m}$ a.s.1., 24.08.2014, leg.\&det. Lj. Melovski (MKMEL! 08068-08071); Kajmakčalan (Nidže): close to Redir - Miletina Kosa, beech forest, 1500-1570 m a.s.l., 11.07.2002, leg. IDSB-Lj. Melovski, det. Lj. Melovski (MKMEL!
08075); Pelister (Baba): Debel Rid - below Golemo Ezero, among silicate blocks, 1800-2000 m a.s.1., 10.07.2003, leg. Lj. Melovski \& J. Miloševski, det. Lj. Melovski (MKMEL! 08076-08081); Pelister (Baba): above v. Niže Pole - towards Debel Rid, among silicate blocks, $1260 \mathrm{~m}$ a.s.l., 12.06.2008, leg.\&det. Lj. Melovski (MKMEL! 08082); Pelister (Baba): Partizanski Vrv - Malo Ezero, among silicate blocks, 2200-2250 m a.s.1., 27.06.2004, leg.\&det. Lj. Melovski (MKMEL! 08083 and 08084); Pelister (Baba): Veternica - Golemo Ezero cirque, silicate stone blocks, $2230 \mathrm{~m}$ a.s.l., 14.07.2016, leg.\&det. Lj. Melovski (MKMEL! 08955-08958); Osogovo-Sasa. On paleogene schists. 1600 m.n.v., 17.VII.1967 (sub D. dilatata), leg.\&det. K. Micevski (sub D. dilatata), rev. C. R. Fraser-Jenkins, confirmed Lj. Melovski (MKNH! 000303-000306); Pelister - around Malo Ezero, on silicate rocks. 2100 m.n.v., 12.VII.1968, leg.\&det. K. Micevski (sub D. dilatata), rev. C. R. FraserJenkins, confirmed Lj. Melovski (MKNH! 000326, 000331, 000332 and 00336); Pelister - around Malo Ezero, on silicate rocks. 2250 m.n.v., 12.VII.1968, leg.\&det. K. Micevski (sub D. dilatata), rev. C. R. Fraser-Jenkins, confirmed Lj. Melovski (MKNH! 000327-000330 and 000333-000335).

Dryopteris carthusiana (Vill.) H.P. Fuchs, Bull. Soc. Bot. Fr. 105: 339 (1958)

$D$. carthusiana is the third member of $D$. dilatata group. Same as the other species of this group, it has very wide distribution in Europe - it is not present only in Portugal and Iceland [2]. Up to this research it was considered as a very rare species in Macedonia, found only on Osogovo Mts. (Osogovski Planini) [5] (Figure 1). This research proved that it has broader distribution though it is still quite rare (Figure 1). It is confined to the localities where the last remnants of alder forests and woodlands are still preserved. Further research is needed to check the data given by old botanists from the beginning of the 19-th century and questioned by Micevski [5].

\section{Existing chorological records}

Osogovo - Sasa: On paleogene schists. 1600 m.n.v., 17.VII.1967, leg.\&det. K. Micevski (MKNH! 000307-000311).

\section{New chorological records}

Bistra-Šar Planina: Children's resort "Bunec" - below the resort, swampy site in alder woodland, $1240 \mathrm{~m}$ a.s.1., 14.08.2007, leg.\&det. Lj. Melovski (MKMEL! 00249 and 00250); Debarca: Belčiško Blato - close to the v. Novo Selo, alder forest, 763 
m a.s.l., 09.06.2009 and 12.07.2009, leg.\&det. Lj. Melovski (MKMEL! 01935, 01939 and 01940); Debarca: Belčiško Blato - close to v. Novo Selo, swampy forest with Alnus glutinosa, $763 \mathrm{~m}$ a.s.l., 26.06.2004, leg.\&det. Lj. Melovski (MKMEL! 08028-08030); Polog: Dolni Polog - v. Jančište (Zabel), alder forest, $390 \mathrm{~m}$ a.s.l., 16.09.2016, leg. Lj. Melovski \& M. Kostadinovski, det. Lj. Melovski (MKMEL! 08985-08991).

It can be concluded that the flora of the Republic of Macedonia consists of 10 Dryopteris species: Dryopteris affinis with one subspecies $-D$. affinis subsp. jessenii, D. borreri, D. filix-mas, D. oreades, D. villarii, D. pallida, D. mindshelkensis, $D$. dilatata, D. carthusiana and D. expansa. However, the knowledge of the Buckler ferns in Macedonia is still incomplete. Presence of some other species cannot be rejected. Future research is needed to prove presence of several hybrid taxa for which there are indications that they can be found in the Republic of Macedonia.

Acknowledgement: I am grateful to my colleagues from the Institute of Biology, Faculty of Natural Sciences and Mathematics at the St. Cyril and Methodius University in Skopje: Dr. Zlatko Levkov and Ms. Slavica Tofilovska for their assistance with microscopic analyses and to Ms. Daniela Jovanovska for her technical assistance, particularly in the preparation of the distribution map. I am also grateful to Vasko Avukatov from the Macedonian Ecological Society for the adaptation of the UTM grid for the map.

\section{REFERENCES}

[1] The Plant List, Version 1.1. (2013). [http://www.theplantlist.org/] (accessed: 1 January 2016).

[2] M. Christenhusz, E. von Raab-Straube, Polypodiopsida, in: Euro+Med Plantbase - The information resource for Euro-Mediterranean plant diversity (2013). [http://ww2.bgbm.org/ EuroPlusMed/query.asp] (accessed: 21 September 2016).

[3] C. R. Fraser-Jenkins, Dryopteris in Spain, Portugal and Macaronesia, Bol. Soc. Broteriana, Ser. 2a, 55 (1982), pp. 175-336.

[4] C. R. Fraser-Jenkins, The species and subspecies in the Dryopteris affinis group, Fern Gaz., 18, 1 (2007), pp. 1-26.

[5] K. Micevski, The Flora of SR Macedonia I/1. Macedonian Academy of Sciences and Arts, Skopje 1985, pp. 1-152.

[6] C. R. Fraser-Jenkins, Dryopteris affinis: a new treatment for a complex species in the European Pteridophyte flora, Willdenowia, 10, 1 (1980), pp. 107-115.
[7] J. Dostál, C. R. Fraser-Jenkins \& T. Reichstein, Dryopteris, in: J. K. Kramer (Ed.), Illustrierte Flora von Mitteleuropa, 1, 1, Berlin, (1984), Berlin-Hamburg, pp. 136-169.

[8] C. R. Fraser-Jenkins, A classification of the genus Dryopteris (Pteridophyta: Dryopteridaceae). Bull. Brit. Mus. (Nat. Hist.), Bot., 14 (1986), pp. 183-218.

[9] C. R. Fraser-Jenkins, Taxonomic and nomenclatural notes 5, Dryopteris, in: Checklist of European Pteridophytes. Sommerfeltia 6, (1987) pp. xxiii. [L. N. Derrick, A. C. Jermy, A. M. Paul (Eds), Oslo, Norway (1987), pp. 1-94].

[10] C. R. Fraser-Jenkins, Dryopteris Adanson, in: Flora Europaea, 2, 1, T. G. Tutin, N. A. Burges, A. O. Chater, J. R. Edmondson, V. H. Heywood, D. M. Moore, D. H. Valentine, s. M. Walters, D. A. Webb (Eds), Cambridge University Press, Cambridge, 1993, pp. 27-30.

[11] M. Gibby, The Dryopteris dilatata complex in Macaronesia and the Iberian Peninsula, Acta Botánica Malacitana, 8, (1983), pp. 59-72.

[12] M. Gibby, Hybridization and speciation in the genus Dryopteris (Pteridophyta: Dryopteridaceae) on Pico Island in the Azores. Pl. Syst. Evol., 149 (1985), pp. 241-252.

[13] L. N. Derrick, A. C. Jermy, A. M. Paul, Checklist of European Pteridophytes, Sommerfeltia Oslo, 6 (1987), pp. 1-94.

[14] H. Piękoś-Mirkowa, The distribution of the Dryopteris dilatata complex in Poland and in Slovakia, Veröff. Geobot. Inst. ETH, Stiftung Rübel, Zürich, 106 (1991), pp. 282-287.

[15] E. Szczęśniak, D. Tlałka, A. Rostański, Key to identification and descriptions of species of Buckler-ferns (Dryopteris Adans.) occurring in Poland. In: Genus Dryopteris Adans. in Poland, E. Szczęśniak, E. Gola (Eds), Polish Botanical Society \& Institute of Plant Biology, University of Wrocław, Wrocław, 2009, pp. 5-34.

[16] L. Ekrt, P. Trávníček, V. Jarolímová, P. Vít, T. Urfus, Genome size and morphology of the Dryopteris affinis group in Central Europe, Preslia, 81 (2009), pp. 261-280.

[17] S. Jessen, W. Bujnoch, G. Zenner, C. Stark, Dryopteris lacunosa - eine neue Art des Dryopterisaffinis-Aggregats (Dryopteridaceae, Pteridophyta), Kochia, 5 (2011), pp. 9-31.

[18] H. Juslén, N. Väre, Wikström, Relationships and evolutionary origins of polyploid Dryopteris (Dryopteridaceae) from Europe inferred using nuclear pgiC and plastid trnL-F sequence data, Taxon, 60, 5 (2011), pp. 1284-1294.

[19] B. Thiers, [continuously updated]. Index Herbariorum: A global directory of public herbaria and associated staff. New York Botanical Garden's Virtual Herbarium, [http://sweetgum.nybg.org/ih/] (accessed: 26 August 2016). 
[20] H. Piękoś-Mirkowa, The ferns of the Dryopteris dilatata complex in Poland, Monogr. Botanicae, 59, Warszawa, 1979, pp. 1-75. (In Polish with English summary.)

[21] H. Piękoś-Mirkowa, Dryopteris affinis (Lowe) Fraser-Jenkins - nowy gatunek we florze Polski [Dryopteris affinis (Lowe) Fraser-Jenkins: a new species in the flora of Poland], Fragm. Fl. Geobot., 27 (1981), pp. 359-370. (In Polish with English summary.)

[22] J. W. Merryweather, British male ferns, Pteridologist, 4, 1 (2002), pp. 12-14.

[23] J. W. Merryweather, Male ferns, Pteridologist, 4, 6 (2007), pp. 173-177.

[24] D. Ivanova, Dryopteris affinis ssp. borreri (Pteridophyta: Dryopteridaceae) in the Bulgarian flora, Fl. Medit, 14 (2004), pp. 201-218.

[25] D. Ivanova, Dryopteris $\times$ ambroseae (Dryopteridaceae: Pteridophyta), a hybrid new to Bulgaria, Phytol. Balcan., 12, 3 (2006), pp. 351-356.

[26] A. Bär, A. Eschelmüller, Aktuelle Taxonomie und Übersicht unserer Funde von Dryopteris affinis (Lowe) Fraser-Jenkins und von Bastarden mit Dryopteris filix-mas, Mitt. Naturwiss. Arbeitskr. Kempten, 42, 1/2 (2007), pp. 21-35.

[27] B. Woziwoda, Morphological diversity of ferns in the Dryopteris affinis group in Central Poland, in: Genus Dryopteris Adans. in Poland, E. Szczęśniak, E. Gola (Eds.), Polish Botanical Society \& In- stitute of Plant Biology, University of Wrocław, Wrocław, 2009, pp. 45-59.

[28] R. Lampinen, Universal Transverse Mercator (UTM) and Military Grid Reference System (MGRS) (2001), [http:// www.luomus.fi/en/utmmgrs-atlas-florae-europaeae] (accessed: 23 September 2016).

[29] Lj. Melovski, B. Markovski, S. Hristovski, D. Jovanovska, V. Anastasovski, S. Klincharov, M. Velevski, N. Velkovski, A. Trendafilov, V. Matevski, M. Kostadinovski, M. Karadelev, Z. Levkov \& D. Kolchakkovski, Regional division of the Republic of Macedonia for the needs of biological databases, Mac. J. Ecol. Env., 15, 2 (2013), pp. 81-111.

[30] D. Tlałka, Dryopteris affinis (Lowe) Fraser-Jenk. s. str. and D. pseudodisjuncta (Tavel ex FraserJenk.) Fraser-Jenk. Nowe gatunki we florze Polski, Acta Botanica Silesiaca, 11 (2015), pp. 173-182.

[31] B. Assyov, A. Petrova, D. Dimitrov, R. Vassilev, Conspectus of the Bulgarian vascular flora - Distribution maps and floristic elements, in: Fourth revised and enlarged edition, B. Assyov, A. Petrova (Eds), Bulgarian Biodiversity Foundation, Sofia, 2012, pp. 1-494.

[32] K. Micevski, The Flora of SR Macedonia I/3. Macedonian Academy of Sciences and Arts, Skopje, 1995, pp. 401-503.

[33] R. L. L. Viane, Dryopteris expansa and D. $\times$ ambroseae (Pteridophyta) new for Belgium, Bull. Soc. Roy, Bot. Belg., 118 (1985), pp. 57-67.

\title{
POДОТ DRYOPTERIS (PTERIDOPHYTA: DRYOPTERIDACEAE) ВО ФЛОРАТА НА РЕПУБЛИАК МАКЕДОНИЈА - ЗО ГОДИНИ ПО ФЛОРАТА НА МИЦЕВСКИ -
}

\author{
Љупчо Меловски
}

Институт за биологија, Природно-математички факултет, Универзитет „Св. Кирил и Методиј“, Скопје, Република Македонија

Оваа статија ги презентира првите наоди на четири нови видови машка папрат (Dryopteris) на територијата на Република Македонија и нови податоци за дистрибуцијата на некои ретки видови од групата на машка папрат.

Dryopteris е еден од најкомплексните родови папрат во Европа. Хибридизацијата и апомиксисот меѓу некои од видовите придонесуваат за тешкотиите и несигурноста за идентификација на одделни видови. Тоа, во комбинација со недостиг на истражување на папратите во Македонија во последните 30 години, резултира со ниско ниво на знаење во рамките на оваа група васкуларни растенија.

Истражувања од областа на флората на Македонија и темелна проверка на два хербариума (MKMEL и MKNH) во Скопје открија присуство на четири нови видови папрат во Македонија: Dryopteris affinis subsp. jessenii, D. oreades, D. mindshelkensis и D expansa. Покрај тоа, презентирани се неколку други локации со ретки видови: D. borreri, D. dilatata и D carthusiana.

Потребно е понатамошно истражување за да се пополнат преостанатите недостатоци, особено во однос на идентификување на хибридите, како и подетална студија за распространување на ретките видови од родот Dryopteris.

Клучни зборови: Dryopteris affinis; Dryopteris oreades; Dryopteris mindshelkensis; Dryopteris expansa; Република Македонија; ретки папрати 
